\title{
Dietary calcium intake relates to bone mineral density in premenopausal women
}

\author{
BY S. J. RA MSDALE, ${ }^{1}$ E. J. BASSEY1* AND D. J. PYE ${ }^{2}$ \\ Nottingham Osteoporosis Research Group, ${ }^{1}$ Department of Physiology and Pharmacology and \\ ${ }^{2}$ Department of Medical Physics, Medical School, Queen's Medical Centre, Nottingham NG7 2UH
}

(Received 14 October 1992 - Revised 29 January 1993 - Accepted 18 March 1993)

\begin{abstract}
Bone density and $\mathrm{Ca}$ intake were assessed in fifty-six healthy premenopausal women, aged 21-47 years. Bone density was measured at the spine (lumbar vertebrae 1-4, anterio-posterior view), the non-dominant femur (neck, Ward's triangle and trochanter) and radius (33\% distal and ultradistal) using dual energy $X$-ray absorptiometry (Lunar DPX-L). The mean values (SD) for bone density $\left(\mathrm{g} / \mathrm{cm}^{2}\right)$ were $1 \cdot 18(0 \cdot 10)$ at the lumbar spine, $0 \cdot 81(0 \cdot 10)$ at the trochanter and for $\mathrm{Ca}$ intake $783(329) \mathrm{mg}$. Bone density values were close to published normal values for young women and the $\mathrm{Ca}$ intakes were close to the recommended levels for the UK. However, there was a wide range especially in dietary Ca intake, and $27 \%$ of the group were at or below $500 \mathrm{mg} / \mathrm{d}$. Correlations between Ca intake and bone density were highly significant at all three femoral sites (neck $r 0.41$; Ward's triangle $r 0.40, P<0.01$; trochanter $r 0.47, P<0.001)$, significant at the spine $(r 0.27, P<0.05)$ but not found at the radius. These correlations were independent of body mass. The low levels of $\mathrm{Ca}$ intake found in a substantial proportion of this selected group of young women and their association with low femoral bone density are cause for concern.
\end{abstract}

Bone mineral density: Calcium: Premenopausal women

Bone density in the 3rd and 4th decades of life in women is increasingly recognized as important for long-term avoidance of osteoporotic fracture (Stevenson et al. 1989). A high 'peak bone mass' can be seen as a safety margin to protect bone strength in the face of inevitable menopausal losses (Law et al. 1991). Some studies relating dietary history and fracture incidence show that a high $\mathrm{Ca}$ diet can reduce the long-term risk of fracture (Matkovic et al. 1979; Holbrook et al. 1988), although not all such studies find this (Cooper et al. 1988; Wickham et al. 1989). Some studies have also shown that low $\mathrm{Ca}$ intake is associated with low bone density in young women (Kanders et al. 1988; Picard et al. 1988) while others have found no association between the two (Mazess \& Barden, 1991). There is debate about the amount of dietary $\mathrm{Ca}$ needed to maintain optimal bone density. The current $U K$ recommended nutritional intake (RNI) is set at $700 \mathrm{mg} / \mathrm{d}$ (Department of Health, 1991). However, studies of Ca balance (Heaney et al. 1977) indicate a requirement in young women of between 1.2 and $1.5 \mathrm{~g} / \mathrm{d}$ and the US National Institutes of Health (1984) recommend an intake of $1.0 \mathrm{~g} / \mathrm{d}$. In two recent studies a threshold was observed at $800 \mathrm{mg} / \mathrm{d}$; $\mathrm{Ca}$ intakes below this amount correlated significantly with bone density but further increases in $\mathrm{Ca}$ were not matched by similar increases in bone density (Kanders $e t$ al. 1988; van Beresteijn et al. 1990). The present report describes dietary Ca intakes in young women and their relationship with bone density at the three sites which fracture most commonly and, therefore, are of concern clinically, namely the spine, femur and radius. 


\section{METHODS}

The subjects were premenopausal women recruited by postal invitation sent to every third name on the age/sex register of a large group practice. Of 160 initial volunteers (response rate $27 \%$ ), fifty-six women aged 21-47 years satisfied the selection criteria and entered the study. Selection criteria included: Caucasian race, no recent injury, no prescribed medication other than oral contraceptives, not pregnant and at least 12 months postpartum. Of the volunteers, $86 \%$ were in paid employment. Those who were currently involved in vigorous physical activity either at work or in their leisure were excluded. Activities likely to influence bone density such as squash, jogging or weight training were cause for exclusion, but swimming or walking were allowed since they have been found to have no influence (Marcus et al. 1992). The district from which they came was predominantly social classes 3 and 4 (Office of Population Censuses and Surveys 1980). Ethical permission was granted by the Medical School Ethical Committee and subjects gave their informed consent. All measurements were made during March and April.

Bone density was assessed, using dual-energy X-ray absorptiometry (Lunar DPX-L; Lunar Radiation Corporation, Madison, WI, USA), in the lumbar spine (lumbar vertebrae 1-4, anterio-posterior view), non-dominant femur and distal radius. Subjects were measured on one occasion using standard procedures. The femoral neck, Ward's triangle and trochanteric regions of the proximal femur and the $33 \%$ distal site of the radius were selected for analysis according to Lunar software V.1.2. In addition an ultradistal site of the radius was selected, defined as a region extending $15 \mathrm{~mm}$ proximally from the point at which the projection of the distal ulna and radius overlap. This definition differs from the Lunar definition for an ultradistal region of interest (UD ROI). It was chosen to simplify the analysis procedure since there is no generally agreed definition for an UD ROI between manufacturers and techniques.

The densitometer was calibrated daily according to the manufacturer's protocol. An $\mathrm{Al}$ step wedge in $150 \mathrm{~mm}$ depth of water (a phantom) was used as an independent weekly check and observed over time. In a period of about 21 months (sixty-eight observations) the slope of the regression of bone mineral density $v$. time for the phantom was $-0.0016 \mathrm{~g} / \mathrm{cm}^{2}$ per year $(-0.13 \% /$ year $)$ which was not statistically significantly different from zero $(t-1 \cdot 1, P=0 \cdot 36)$. In vivo repeatability within our laboratory was determined from repeat measurements made about 1 week apart in forty-three subjects. The coefficient of variation for the respective sites was derived from the standard error of the mean difference divided by the overall mean (Healy 1958), and found to be $1.4 \%(n 21), 1.9-4.0 \%$ ( $n$ 43) and $1 \cdot 2-2 \cdot 5 \%(n 43)$ in the lumbar spine, femur and radius respectively. The effective dose equivalent (EDE) is less than $1 \cdot 0 \mu \mathrm{Sv}$ per scan for women of reproductive capacity. However, as a precaution, subjects were measured within $10 \mathrm{~d}$ of the start of their previous menstrual cycle.

Height was measured to the nearest $0.005 \mathrm{~m}$ using a free-standing stadiometer. Body mass was measured to the nearest $0.05 \mathrm{~kg}$ (Marsdens balance scales). Body mass index (BMI) was derived from the mass $(\mathrm{kg})$ divided by the square of the height $(\mathrm{m})$.

A structured food frequency questionnaire administered by one interviewer was used to assess the level of $\mathrm{Ca}$ nutrition. The questionnaire contained a list of twelve different foods known to have a high Ca content including dairy, fish, fruit, vegetable and cereal products. Taking each food, one at a time, subjects were asked whether they included it in their habitual diet. They were then asked how frequently they consumed this food (daily, once weekly etc.) and then how much of it. The interviewer explored appropriately for portion size, e.g. pints of milk, ounces of cheese (including distinctions between 'hard' and 'soft' cheese), or pots of yoghurt ( $125 \mathrm{~g}$ etc.). Ingredients included in cooking such as milk or cheese were 
Table 1. Physical characteristics, calcium intake and bone mineral density of premenopausal Caucasian women

(Mean values and standard deviations for fifty-six subjects)

\begin{tabular}{|c|c|c|c|c|}
\hline & Mean & SD & Range & Median \\
\hline Age (years) & $31 \cdot 5$ & 5.69 & $21-47$ & $30 \cdot 5$ \\
\hline Height (m) & 1.63 & 0.06 & $1.52-1.76$ & 1.63 \\
\hline Wt (kg) & 63.6 & $9 \cdot 01$ & $48 \cdot 0-91 \cdot 0$ & $62 \cdot 0$ \\
\hline $\operatorname{BMI}\left(\mathrm{kg} / \mathrm{m}^{2}\right)$ & $24 \cdot 0$ & $3 \cdot 44$ & $18 \cdot 7-33 \cdot 4$ & $23 \cdot 3$ \\
\hline $\mathrm{Ca}$ intake (mg/d) & $867 \cdot 1$ & $709 \cdot 6$ & $200-5500$ & $810 \cdot 0$ \\
\hline & $782 \cdot 9^{*}$ & $328 \cdot 9^{*}$ & $200-1550^{*}$ & $787 \cdot 5^{*}$ \\
\hline \multicolumn{5}{|l|}{ Bone density $\left(\mathrm{g} / \mathrm{cm}^{2}\right)$} \\
\hline Lumbar (L1-L4) & $1 \cdot 18$ & $0 \cdot 10$ & $0.97-1 \cdot 44$ & $1 \cdot 17$ \\
\hline Femur: Neck & 099 & $0 \cdot 10$ & $0.73-1 \cdot 26$ & 0.98 \\
\hline Ward's triangle & 0.96 & $0 \cdot 13$ & $0 \cdot 65-1 \cdot 29$ & 0.96 \\
\hline Trochanter & 0.81 & $0 \cdot 10$ & $0.53-1.04$ & 0.81 \\
\hline \multirow{2}{*}{$\begin{array}{l}\text { Radius: Ultradistal } \\
33 \% \text { Distal }\end{array}$} & 0.46 & $0-05$ & $0 \cdot 32-0.58$ & 0.47 \\
\hline & 0.83 & 0.05 & $0.72-0.95$ & 0.83 \\
\hline
\end{tabular}

BMI, body mass index (weight/height ${ }^{2}$ ). L1-L4, lumbar vertebrae $1-4$.

* Excluding one individual with high $C$ a intake.

also explored. The interviewer then used this information along with standard food tables (Holland et al. 1991) to arrive at a semi-quantitative estimate of average daily Ca intake for each woman.

In a separate study of twenty-nine women the food frequency questionnaire was administered twice with a 6 -month interval. The two mean estimates of Ca intake (mg) were 1075 (SD 236) and 1102 (SD 290); they correlated well $(r 0.94, P<0.001)$ and the mean difference was 28 (SD 106) $\mathrm{mg}$ giving a coefficient of variation of $6.9 \%$. Comparison of the food frequency method with a $3 \mathrm{~d}$ weighed food intake in twenty-seven women showed that the two different methods were well correlated $(r 0.71, P<0.01)$. Mean Ca intakes were 1183 (SD 225) $\mathrm{mg}$ for the food frequency assessment and 1204 (SD 310) $\mathrm{mg}$ for the $3 \mathrm{~d}$ weighed intake. The mean difference was 22.0 (SD 217) $\mathrm{mg}$.

Data are expressed as means (SD) unless otherwise stated. Pearson product moment correlations were used to explore simple relationships between the variables and two-tailed significance levels were obtained. The degrees of freedom were 54 ( $n$ 56) unless otherwise stated. Stepwise multiple-regression analyses (SPSSX3; SPSS Inc., 1988) were used to find which factors explained the most variance, using each bone density site as a separate dependent variable.

\section{RESULTS}

Descriptive results for all variables are given in Table 1. The women were on average similar in physique to a large representative British sample aged 25-34 years (height $1.64 \mathrm{~m}$, body mass $64.5 \mathrm{~kg}$, BMI 24.0; Fentem, 1992). One individual, who had an unusually high $\mathrm{Ca}$ intake $(5500 \mathrm{mg} / \mathrm{d})$ due to excessive consumption of cheese, was excluded from all analyses involving $\mathrm{Ca}$. The mean daily $\mathrm{Ca}$ intake for the remaining group of fifty-five women was $783 \mathrm{mg}$, with an approximately normal distribution.

The relationships between bone density, body composition and $\mathrm{Ca}$ intake are given in Table 2. The bone densities were significantly correlated with each other except for the spine and the $33 \%$ distal site of the radius. Height and body mass were independent. Ca 
Table 2. Pearson product moment correlation coefficients ( $r$ ) between bone density, anthropometry and calcium intake

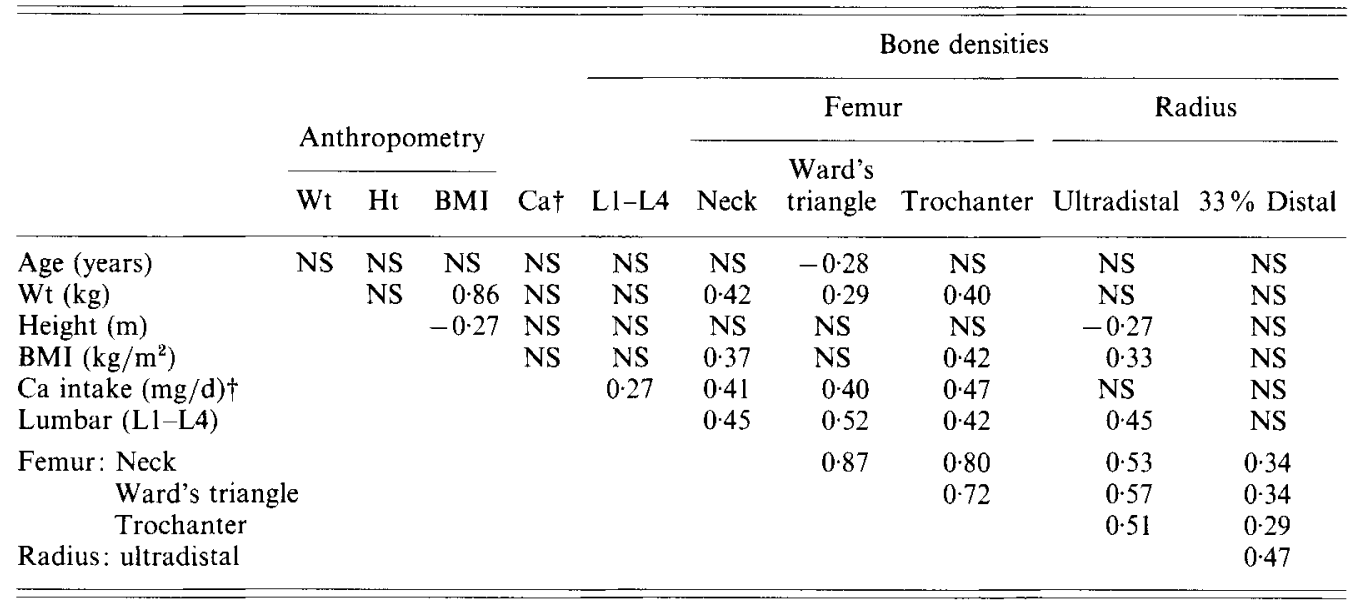

BMI, body mass index (weight/height ${ }^{2}$ ); NS, not significant.

Critical $r: P<0.050 .26 ; P<0.010 .31 ; P<0.0010 .42$.

$\dagger(n 55)$.

intake was correlated with all bone densities except at the radial sites; the trochanter was the most highly correlated $(P<0.001$; see Fig. 1) followed by the femoral neck, Ward's triangle and the lumbar spine $(P<0.01, P<0.01$ and $P<0.05$ respectively). Femoral bone density was also correlated with body mass, the relationship being more significant for the neck and trochanter $(P<0.01)$ than for Ward's triangle $(P<0.05)$. Similarly, bone density for the neck and trochanter but not for Ward's triangle were correlated with BMI. For the radius, bone density for the ultra-distal site was negatively correlated with height $(P<0.05)$ and positively correlated with BMI $(P<0.05)$. No significant correlations were observed at the $33 \%$ distal site except with other bone densities. Ca intake was not correlated with body mass nor BMI. An age-related decline was observed only at Ward's triangle $(P<0.05)$.

All measured variables which were significant in simple regression were entered into stepwise multiple-regression analysis and the equations below provide the best descriptions found. Bone density is expressed as $\mathrm{g} / \mathrm{cm}^{2}$ and the explained variance is given as a percentage.

Lumbar spine: $0.086 \mathrm{Ca}(\mathrm{g})+1 \cdot 108$

$R 0 \cdot 27,7 \%$

femoral neck: $0.115 \mathrm{Ca}(\mathrm{g})+0.004$ mass $(\mathrm{kg})+0.625$

$R 0 \cdot 56,31 \%$;

Ward's triangle : $0.145 \mathrm{Ca}(\mathrm{g})-0.006$ age (year) +0.004 mass $(\mathrm{kg})+0.810 \quad R 0.54,29 \%$;

trochanter: $0 \cdot 137 \mathrm{Ca}(\mathrm{g})+0 \cdot 011 \mathrm{BMI}+0 \cdot 436$

$R 0 \cdot 60,36 \%$;

radius, ultradistal: $0 \cdot 004 \mathrm{BMI}+0 \cdot 363$

$R 0 \cdot 30,9 \%$;

radius, $33 \%$ : no variables were found.

$\mathrm{Ca}$ intake remained significant at all sites except the radius and its contribution to the total explained variance ranged from $7 \%$ at the spine to $20 \%$ at the trochanter. In addition either body mass or BMI were significant at the femur and radius. Age remained significant at Ward's triangle. 


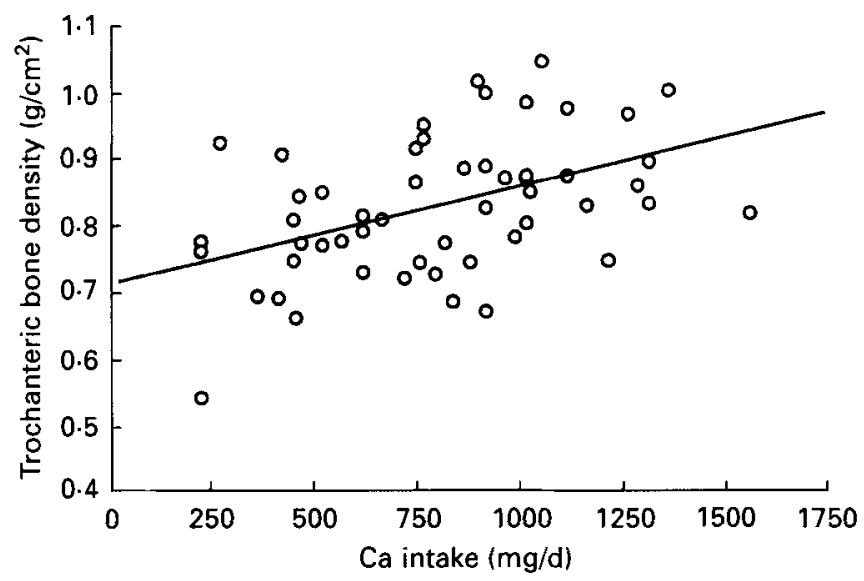

Fig. 1. Dietary calcium intake and femoral bone density in premenopausal women. Each point represents one value for one individual measured on one occasion; (- $)$, the least-squares best-fit regression line $(r 0.47$, $P<0.001)$. For details of subjects and procedures, see pp. 78-79.

\section{DISCUSSION}

The repeatability of measurements of bone density using dual energy X-ray absorptiometry is now extremely good (Johnson \& Dawson-Hughes, 1991), the scan times are short and the radiation dose low, so accurate information at all potential fracture sites can be obtained conveniently and safely. Mean bone densities for our group were not dissimilar to those reported in other studies of young healthy women which used the same methodology (Rockwell et al. 1990; Snowharter et al. 1990). The bone densities at the different sites were in general significantly correlated with each other, but some correlations were low. This confirms other reports (Seldin et al. 1988; Wahl et al. 1988) and shows that prediction of densities from one site to another for an individual would not be accurate for clinical diagnosis. The site of interest should be measured directly.

Assessment of dietary intake of any nutrient inevitably has a low repeatability compared with measurements of variables such as bone density. However, in general, food frequency methods compare quite well with weighed methods (Seldin et al. 1988; Wahl et al. 1988), and the repeatability and validity of the food frequency method adopted in the present study was good. The mean Ca intake of 783 (SD 329) $\mathrm{mg}$ was close to the RNI of $700 \mathrm{mg}$ (Department of Health, 1991), but the range was wide with fifteen individuals $(27 \%$ of the group) below $500 \mathrm{mg}$. Other reported studies of selected groups of young women give mean intakes of 576 (SD 383) mg (Picard et al. 1988), 871 (SD 318) $\mathrm{mg}$ (Kanders et al. 1988) and 909 (SD 351) mg (Mazess \& Barden, 1991). Kanders et al. (1988) selected subjects for high levels of activity and they report a significant relationship between intakes of $\mathrm{Ca}$ and total energy. Variation in intakes was similar and rather large in all these studies; many individuals, therefore, have habitual dietary intake well below recommended amounts. Whether these intakes are adequate or not depends on efficiency of absorption (Heaney et al. 1977; Gallagher et al. 1979) as well as body size and individual needs.

Despite a wide range, age was not significant in the present study, except at Ward's triangle $(P<0.05)$. This may be because the mean age was only 31 years, so half the group may not yet have attained their peak bone mass (Rodin et al. 1990). Some studies show little or no age-related change in pre-menopausal women (Gallagher et al. 1987; Lindsay et al. 1992), and others show that bone density begins to decline slightly from about 30 years of age, well before the menopause (Riggs et al. 1981; Hansson \& Roos, 1986; Smith, 1987; 
Melton III et al. 1988, 1989). Our finding accords closely with Stevenson et al. (1989) who found a steep decline at Ward's triangle with only a slight change at the lumbar spine and other femoral areas.

$\mathrm{Ca}$ intake had a consistent, highly significant and numerically rather similar association with bone density at lumbar and all femoral sites. Although the variance explained by $\mathrm{Ca}$ intake was low, the outcome suggests that some intakes are inadequate. The slopes of the relationships suggest that, on average, increasing $\mathrm{Ca}$ intake by $200 \mathrm{mg}$ could increase bone density by a few percent which might be useful for future protection from fracture. A number of studies in postmenopausal women (Recker et al. 1977; Ettinger et al. 1987; Riis et al. 1987; Smith et al. 1989; Nelson et al. 1991) and at least one in men (Kelly et al. 1990) have found associations between $\mathrm{Ca}$ intake and bone density at various sites, but only two other studies in premenopausal women have been found (Kanders et al. 1988). These both showed an association between radial bone density and $\mathrm{Ca}$ intake but findings for the spine were less convincing and the femur was not examined.

Femoral bone densities were also significantly and selectively associated with either body mass or BMI which is consistent with the view that these bone densities are sensitive to load-bearing and gravitational effects on carried body mass. Slight stature was associated with low bone density only in the radius. This is perhaps due to the heterogeneity of build within the group; lack of correlation between height and body mass is unusual. Those who were light or thin did appear to have lower bone densities at the hip and so they are likely to be more at risk in the long term from fractured femur.

Larger people may have greater energy intakes, and this in turn may be associated with higher $\mathrm{Ca}$ intakes. However, $\mathrm{Ca}$ intake was not related to body mass and multipleregression analysis confirmed the independent effects of both body composition and dietary $\mathrm{Ca}$. High levels of activity have also been thought to lead to increased Ca intake for similar reasons (Kanders et al. 1988; Kelly et al. 1990). However, it is necessary to distinguish between high levels of activity produced by prolonged moderate exercise which increases energy expenditure but is not thought to affect bone density (Marcus et al. 1992), and that produced by intermittent brief bouts of intense exercise which probably does affect bone density (Gleeson et al. 1990; Gutin \& Kasper, 1992). The latter was an exclusion criterion for the present study; it seems unlikely, therefore, that the relations found between $\mathrm{Ca}$ intake and bone density could be attributed to variations in activity levels within the group.

The low levels of dietary Ca found in this selected group and their association with low bone density are cause for concern. If bone densities are below the optimum before the menopause then the likelihood of osteoporotic fracture in later life is increased.

This work was funded by the Wellcome Trust Grant No. 031762/2/90/2/1.5/LHS/SD/JJ. The authors would like to thank the Medical Physics technicians, Mandy Blaze, Catherine Flint, Ann Jowett and Lisa Odam, who carried out the bone densitometry and Professor C. Chilvers and Ms C.Coupland, Department of Public Health Medicine and Epidemiology, for statistical advice.

\section{REFERENCES}

Cooper, C., Barker, D. J. P. \& Wickham, C. (1988). Physical activity, muscle strength, and calcium intake in fracture of the proximal femur in Britain. British Medical Journal 297, 1443-1446.

Department of Health (1991). Dietary Reference Values For Food Energy and Nutrients For the UK. Report on Health and Social Subjects no. 41. London: H. M. Stationery Office.

Ettinger, B., Genant, H. K. \& Cann, C. E. (1987). Postmenopausal bone loss is prevented by treatment with lowdosage estrogen with calcium. Annals of Internal Medicine 106, 40-45.

Fentem, P. H. (1992). Allied Dunbar National Fitness Survey: Main Findings Health Education Authority and Sports Council. 
Gallagher, J. C., Goldgar, D. \& Moy, A. (1987). Total bone calcium in normal women: effect of age and menopause status. Journal of Bone and Mineral Research 2, 491-496.

Gallagher, J. C., Riggs, B. L., Eisman, J., Hamstra, A., Arnaud, S. B. \& DeLuca, H. F. (1979). Intestinal calcium absorption and serum vitamin D metabolites in normal subjects and osteoporotic patients. Journal of Clinical Investigation 64, 729-736.

Gleeson, P. B., Protas, E. J., LeBlanc, A. D., Schneider, V. S. \& Evans, P. J. (1990). Effects of weight lifting on bone mineral density in premenopausal women. Journal of Bone and Mineral Research 5, 153-158.

Gutin, B. I. \& Kasper, M. J. (1992). Can vigorous exercise play a role in osteoporosis? A review Osteoporosis International 2, 55-59.

Hanson, T. \& Roos, B. (1986). Age changes in the bone mineral of the lumbar spine in normal women. Calcified Tissue International 38, 249-251.

Healy, M. J. R. (1958). Variation within individuals within human biology. Human Biology 30, 210-218.

Heaney, R. P., Recker, R. R. \& Saville, P. D. (1977). Calcium balance and calcium requirements in middle-aged women. American Journal of Clinical Nutrition 30, 1603-1611.

Holbrook, T. L., Barrett-Connor, E. \& Wingard, D. L. (1988). Dietary calcium and risk of hip fracture: 14-year prospective population study. Lancet 2, 1046-1049.

Holland, B., Welch, A. A., Unwin, I. D., Buss, D. H., Paul, A. A. \& Southgate, D. A. T. (1991). McCance \& Widdowson's The Composition of Foods, 5th ed. Cambridge: Royal Society of Chemistry.

Johnson, J. \& Dawson-Hughes, B. (1991). Precision and stability of dual-energy X-ray absorptiometry measurements. Calcified Tissue International 49, 174-178.

Kanders, B., Dempster, D. W. \& Lindsay, R. (1988). Interaction of calcium nutrition and physical activity on bone mass in young women. Journal of Bone and Mineral Research 3, 145-149.

Kelly, P. J., Pocock, N. A., Sambrook, P. N. \& Eisman, J. A. (1990). Dietary calcium, sex hormones, and bone mineral density in men. British Medical Journal 300, 1361-1364.

Law, M. R., Wald, N. J. \& Meade, T. W. (1991). Strategies for prevention of osteoporosis and hip fracture. British Medical Journal 303, 453-459.

Lindsay, R., Cosman, F., Herrington, B. S. \& Himmelstein, S. (1992). Bone mass and body composition in normal women. Journal of Bone and Mineral Research 7, 55-63.

Marcus, R., Drinkwater, B., Dalsky, G., Dufek, J., Raab, D., Slemenda, C. \& Snowharter, C. (1992). Osteoporosis and exercise in women. Medicine and Science in Sport and Exercise 24, S301-307.

Matkovic, V., Kostial, K., Simonovic, I., Buzina, R., Brodarec, A. \& Nordin, B. E. C. (1979). Bone status and fracture rates in two regions of Yugoslavia. American Journal of Clinical Nutrition 32, 540-549.

Mazess, R. B. \& Barden, H. S. (1991). Bone density in premenopausal women - effects of age, dietary intake, physical activity, smoking, and birth-control pills. American Journal of Clinical Nutrition 53, 132-142.

Melton, L. J. III, Kan, S. H., Wahner, H. \& Riggs, B. L. (1988). Lifetime fracture risk: an approach to hip fracture risk assessment based on bone mineral density and age. Journal of Clinical Epidemiology 41, 985-994.

Melton, L. J. III, Kan, S. H., Frye, M. A., Wahner, H. W., O'Fallon, W. M. \& Riggs, B. L. (1989). Epidemiology of vertebral fractures in women. American Journal of Epidemiology 129, 1000-1011.

National Institutes of Health (1984). Consensus Development Conference on Osteoporosis. Journal of American Medical Association 252, 799-802.

Nelson, E. M., Fisher, E. C., Dilmanian, F. A. \& Evans, W. J. (1991). A one year walking program and increased dietary calcium in postmenopausal women: effects on bone. American Journal of Clinical Nutrition 53, $1304-1311$

Office of Population Censuses and Surveys (1980). Classification of Occupations. London: H. M. Stationery Office.

Picard, D., Ste-Marie, L. G., Coutu, D., Carrier, L., Chartrand, R., Lepage, R., Fugère, P. \& D'Amour, P. (1988). Premenopausal bone mineral content relates to height, weight and calcium intake during early adulthood. Bone and Mineral 4, 299-309.

Recker, R. R., Saville, P. D. \& Heaney, R. P. (1977). Effect of estrogens and calcium carbonate on bone loss in postmenopausal women. Annals of Internal Medicine 87, 649-655.

Riggs, B. L., Wahner, H. W., Dunn, W. L., Mazess, R. B., Offord, K. P. \& Melton, L. J. (1981). Differential changes in bone mineral density of the appendicular and axial skeleton with aging. Journal of Clinical Investigation 67, 328-335.

Riis, B., Thomsen, K. \& Christiansen, C. (1987). Does calcium supplementation prevent postmenopausal bone loss? New England Journal of Medicine 316, 173-177.

Rockwell, J. C., Sorensen, A. M., Baker, S., Leahey, D., Stock, J. L., Michaels, J. \& Baran, D. T. (1990). Weight training decreases vertebral bone density in premenopausal women-A prospective study. Journal of Clinical Endocrinology and Metabolism 71, 988-993.

Rodin, A., Murby, B., Smith, M. A., Caleff, M., Fentiman, I., Chapman, M. G. \& Fogelman, 1. (1990). Premenopausal bone loss in the lumbar spine and neck of femur: a study of 225 Caucasian women. Bone 11, 1-5.

Seldin, D. W., Esser, P. D. \& Alderson, P. O. (1988). Comparison of bone density measurements from different skeletal sites. Journal of Nuclear Medicine 29, 168-173.

Smith, E. L., Gilligan, C., Smith, P. E. \& Sempos, C. T. (1989). Calcium supplementation and bone loss in middleaged women. American Journal of Clinical Nutrition 50, 833-842. 
Smith, R. (1987). Osteoporosis: cause and management. British Medical Journal 294, 329-332.

Snowharter, C., Bouxsein, M., Lewis, B., Charette, S., Weinstein, P. \& Marcus, R. (1990). Muscle strength as a predictor of bone mineral density in young women. Journal of Bone and Mineral Research 5, 589-595.

SPSS Inc. (1988).

Stevenson, J. C., Lees, B., Devenport, M., Cust, M. P. \& Ganger, K. F. (1989). Determinants of bone density in normal women: risk factors for future osteoporosis? British Medical Journal 298, 924-927.

van Beresteijn, E. C. H., van't Hof, M. A., Schaffsma, G., de Waard, H. \& Duursma, S. A. (1990). Habitual dietary calcium intake and cortical bone loss in premenopausal women: a longitudinal study. Calcified Tissue International 47, 338-344.

Wah!, R. L., Waldmann, S. \& Shapiro, B. (1988). Dual-photon bone mineral density in the proximal femur: correlation by site. Nuclear Medicine Communications 9, 53-58.

Wickham, C. A. C., Walsh, K., Cooper, C., Barker, D. J. P., Margetts, B. M., Morris, J. \& Bruce, S. A. (1989). Dietary calcium, physical activity, and risk of hip fracture : a prospective study. British Medical Journal 299 , $889-892$. 